\title{
Four languages from the lower end of the typology of locative predication*
}

MICHAEL DUNN, ANNA MARGETTS, SERGIO MEIRA, AND ANGELA TERRILL

\section{Abstract}

As proposed by Ameka and Levinson (this issue) locative verb systems can be classified into four types according to the number of verbs distinguished. This article addresses the lower extreme of this typology: languages which offer no choice of verb in the basic locative function (BLF). These languages have either a single locative verb, or do not use verbs at all in the basic locative construction ( $B L C$, the construction used to encode the $B L F)$. A close analysis is presented of the behavior of BLF predicate types in four genetically diverse languages: Chukchi (Chukotko-Kamchatkan, Russian Arctic), and Lavukaleve (Papuan isolate, Solomon Islands), which have BLC with the normal copula/existential verb for the language; Tiriyo (Cariban/Taranoan, Brazil), which has an optional copula in the BLC; and Saliba (Austronesian/Western Oceanic, Papua New Guinea), a language with a verbless clause as the BLC. The status of these languages in the typology of positional verb systems is reviewed, and other relevant typological generalizations are discussed.

\section{Introduction}

Ameka and Levinson (this issue) delineate a functional domain called the basic locative function (BLF). The BLF comprises the unmarked expression of the spatial relationship between Figure and Ground (Talmy $1975,1985,2000)$, such as is produced in the complete clause answer to where-questions (Zlatev 1997, 2006). The construction used to encode the BLF is called the basic locative construction (BLC). Not all kinds of Figure-Ground relationships are described using the BLC. Wilkins and colleagues have proposed an implicational hierarchy for what types of Figure-Ground relationship enter into this BLC (Kita and Walsh Dickey 1998: 55-69; Ameka and Levinson this issue). Within this BLC, specific 
languages further differ as to the semantic elaboration of the verbal component of the predicate. It is of course not the case that all languages include semantically rich verbs in the construction used for the $\mathrm{BLF}$, and it is the purpose of this article to explore the lower end of the range of typological variation. The four languages presented in this article are examples of the "zero-" and "one verb" type in the Ameka and Levinson typology - languages which offer no choice of verb in the basic locative construction, either because the basic locative construction only occurs with one verb (usually some kind of copula), or because the basic locative construction is nonverbal. These languages might likewise be characterized as "existence focus" languages, contrasting to "position focus" languages, which use verbs in the BLC specifying dispositional information (Durst-Andersen 2006). The languages in question belong to four unrelated language families: Saliba (Austronesian/ Western Oceanic; Margetts 1999), Tiriyó (Cariban/Taranoan; Meira 2007), Chukchi (Chukotko-Kamchatkan; Dunn 1999), and Lavukaleve (Papuan isolate; Terrill 2003). Saliba is spoken in Papua New Guinea, relatively close to Lavukaleve in the Solomon Islands, while Chukchi is spoken in Kamchatka (Eastern Siberia), and Tiriyó in the SurinamBrazil border area (South America). In Saliba, the basic locative function is expressed by a verbless clause; in Tiriyó, by a clause with an optional copula; in Chukchi and in Lavukaleve, by a normal copular/ existential clause. In no sense do these languages represent a statistical sample of the diversity in the typological domain. Language selection was opportunistic, in that the languages chosen are the fieldwork languages of the authors, and that targeted fieldwork investigation is necessary for the exploration of this little described area of linguistic variation. These languages are united in being the least elaborated in the dimensions considered by the Ameka and Levinson typology of the BLF construction, but they are nevertheless important to consider since the typology was devised with the results of the investigation of these languages in mind.

In the following four sections, the way the four languages realize the BLC is described (Saliba in Section 2, Tiriyó in Section 3, Chukchi in Section 4, and Lavukaleve in Section 5). In each case the description is based on work carried out by a fieldworker, incorporating results obtained using the Picture Series for Positional Verbs (PSPV) (Ameka et al. 1999) elicitation tool, supplemented by the Topological Relations Picture Series tool (TRPS) (Bowerman and Pederson 1993).

In Section 6, the position of these languages in the proposed typology is reviewed and some points of possible theoretical interest are discussed. 


\section{Saliba}

The basic locative function is expressed in Saliba by a nonverbal clause. In the answer to a where-question, the particle ede occurs between the expressions of Figure and Ground, and the Ground expression is followed by the general postposition unai (SG) / udiyedi ( $\mathrm{PL}$ ) (reflecting the number of the Figure expression). The Figure is obligatorily expressed by a free pronoun but may in addition be lexically expressed, by a noun phrase marked by the clitic $w a$ (GIVEN), as shown in (1) and (2).

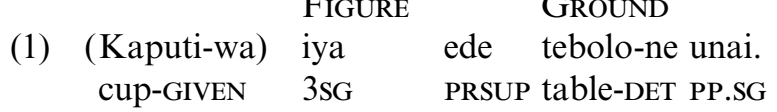

'(The cup) it is on the table.'

(2) (Kokolaka-wa) siya ede kisini-ne udiyedi. rat-GIVEN 3PL PRSUP kitchen-DET PP.PL '(The rats) they are in the kitchen.'

In its basic form the BLC describes the canonical location with respect to the Ground (on table, on chair, in house ...) (Sinha 1988). In order to describe noncanonical locations the BLC is extended by a locative noun (Sinha and Kuteva 1995). The simple BLC cannot be used to describe the scene in (3), because it would then express the canonical location 'in the kennel'.

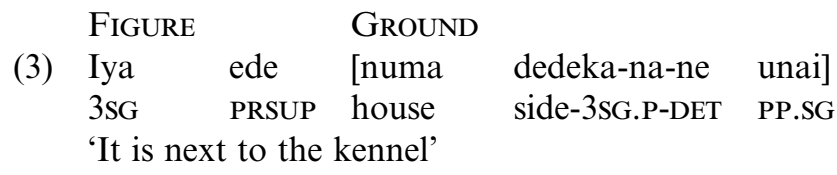

As Examples (1)-(3) show, the Ground expression (including the locative noun) is typically marked by the definiteness clitic ne. The general postposition unai can express a range of functions: it introduces e.g., locations, goals, sources, or instruments. The particle ede has no verbal properties (in particular, the obligatory subject prefix of verbs is absent; Margetts 1999: 11). It marks the preceding element as given information, as in the following example.
(4) Hewa-hewali-o-wa se-kai-kaikewa-i- $\varnothing$ na kabo RED-young.man-PL-GIVEN 3PL-RED-look.at-APP-3SG.O CONJ TAM ye-maliwai.

3sG-vomit

'The young men were watching her and then she vomited.' 
Ye-maliwai ede kwateya se-tau-masahala

3SG-vomit PRSUP yam 3PL-go-appear

'As she vomited yams appeared' (Margetts 1999: 17)

$E d e$ also stands between topic and focus in nonverbal clauses. Besides the BLC ede occurs in equational/identity clauses ('my name ede Martha' = 'my name is Martha'). As a discourse marker, ede functions as a connective, indicating the relation between clauses by marking the preceding clause as presupposed.

Certain scenes in the two elicitation tools (TRPS and PSPV) are typically described by verbal clauses rather than by the BLC. This is the case for scenes with a Figure which is animate, a Figure that is "hanging" or "sticking", or constitutes damage or a cavity (as in a crack in a vase). For scenes with an animate Figure, clauses with positional verbs are common (sit, stand, lie, hang). In locative constructions with verbs, the relative order of verb and Ground phrase is free.

(5) (Simai-wa) ye-tu-tuli leiyaha-ne unai.

cat-GIVEN 3SG-RED-sit mat-DET PP.SG

'(The cat) is sitting on the mat.'

For other scenes the use of positional verbs tends to be only marginally acceptable. For many scenes there is no obvious verb that could describe the depicted relation (the cup doesn't sit, stand, or lie on the table). Positional verbs build a four-member paradigm: tuli 'sit', tolo 'stand', keno 'sleep/lie', and kabasi 'hang'. They are defined as a form class by their behavior in terms of reduplication. Positionals express an inchoative/ change-of-state meaning in the simplex form ye-tuli 'he sat down' but a state in the reduplicated form ye-tutuli 'he's sitting'. ${ }^{1}$ In contrast, active roots reduplicate to express an ongoing or habitual activity. Stative roots either do not allow reduplication, or they reduplicate to express an inchoative reading, a habitual reading, or a reading as a temporary state of being (see [6]).

$\begin{array}{llllll}\text { seya } & \text { yo } & \text { boxi-wa } & \text { kewa-di } & \text { ena } & \text { ye-to-tolo } \\ \text { chair } & \text { CONJ } & \text { box-GIVEN } & \text { top-3PL.o } & \text { PP.SG } & \text { 2sG-RED-stand }\end{array}$

'He was standing on top of the chair and the box' (Margetts 1999:

30)

There is no general existential verb and it can be quite difficult to find a verb to describe certain scenes. The verb bawabawa 'stay, live at' is sometimes accepted for scenes from the two picture books. But it seems to have a flavor of habituality and duration rather than describing purely a location. 
(7) ? (Kaputi-wa) ye-bawa-bawa tebolo-ne unai. cup-GIVEN 3SG-RED-stay table-DET PP.SG '(The cup) is staying on the table.'

When verbal clauses are used for describing the location of inanimate objects there is a clear preference to use transitive/causative verbs rather than intransitive ones. For example, if a verbal clause is used at all it tends to describe the act of putting the object in the location rather than the object being in that location.

(8) (Kaputi-wa) se-tole- $\varnothing$ tebolo-ne unai. cup-GIVEN 3PL-put-3sG.o table-DET PP.SG 'They put (the cup)/it on the table.'

The verbal constructions in (6), (7) and (8) can always be combined with the BLC. The order of verb and Ground phrase is again free.

(Figure) Figure Verb Ground

(9) (Kaputi-wa) iya ede se-tole- $\varnothing$ tebolo-ne unai. cup-GIVEN 3SG.EMPH PRSUP 3PL-put-3sG.o table-DET PP.SG 'They put (the cup) on the table.' (The cup, it is, they put it on the table)

There is no existential verb or copula in Saliba. Negative existential constructions consist of NEG + FigurE (+GROUND PHRASE)

(10) Nige waga (worpu-ne unai).

NEG boat wharf-DET PP.SG

'There is no boat (at the wharf).'

Affirmative existential constructions stating the existence of an entity in a location look like the BLC without the free pronoun and the presupposition particle ede. The relative order of Figure and Ground phrase is grammatically free but possibly the order GROUND PHRASE - FIGURE is preferred.

\section{GROUND FIGURE}

(11) a. Numa-ne udiyedi kokolaka.

house-DET PP.PL rat

Figure Ground

'There are rats in the house.'

b. Kokolaka numa-ne udiyedi. rat house-DET PP.PL

'There is no boat at the wharf.' 


\section{Tiriyó}

In Tiriyó, answers to where-questions are typically copular sentences, without further special characteristics. Example (12) illustrates a typical where-question; (13) and (14) show possible answers (note that the Figure, if already mentioned in the question, is usually omitted in the answer). Examples (15)-(17) show a few examples of nonlocative copular sentences. Parenthetical elements are optional. ${ }^{2}$ Numbers in brackets refer to the PSPV picture to which the example in question was an answer (if this was the case). In all cases the basic structure is Figure and GROUND PHRASE (either order), with an optional copula nai in between.

(12) anpo (nai,) enï-pisi

where (3.COP) container-DIM

'Where is the cup?'

FIGURE

GROUND

enï-pisi

(nai,) apëi juuwë

container-DIM 3.COP table on.top.of

'The cup is on (top of) the table.' [1]

GROUND

FiguRE

apëi juuwë (nai,) enï-pisi

table on.top.of 3.COP container-DIM

'The cup is on (top of) the table.' [1]

(15) ji-pawana (nai,) tarëno me

1 -friend 3.COP Tiriyó DENOM

'My friend is a Tiriyó.'

(16) kure (nai,) ë-pï

well COP 2-wife

'Your wife is well.'

j-akoron (nai,

1-companion COP Spike

'My companion is Spike.'

Further extensions of copular sentences involve adding extra adverbs, including notions that, in Indo-European languages, usually occur as adjectives (e.g., colors, 'pretty', 'new', 'well', also numbers) or even nouns ('night', 'day'). The most frequent such adverbs are listed in (18) (source stems are given for derived adverbs); (19) has a sentence example. Note that adverbials are used to indicate noncanonical orientation of the Figure (e.g., tïntaa po 'on its mouth' = 'upside down', when referring to bottles).

(18) tamenje 'coiled' (amemï 'coil [tr.]')

tomoihtëe 'hung/hanging' (amoihtë 'hang [tr.]') 
(19)

$\begin{array}{lll}\text { tëkïise } & \text { 'glued/pasted' (ekïkï 'paste, glue [tr.]') } & \\ \text { tïpunkae } & \text { 'pierced' (puuka 'pierce, blow [tr.]') } & \\ \text { tïkonkae } & \text { 'pierced' (konka 'pierce, pinch [tr.]') } & \\ \text { tahpame } & \text { 'sitting' (related to tahpaka 'sit [tr.]') } & \\ \text { sokame } & \text { 'standing' (related to sokahtë 'stand [tr.]') } \\ \text { tupae } & \text { 'lying down' } & \\ \text { patëtëme } & \text { 'crossed'; 'twisted' } & \\ \text { pakoro pë nai, wïtoto i-kuhtu } & \text { tomoihëe } \\ \text { house/wall on 3.cop person 3-representation hanging } \\ \text { 'The (person's) photograph is on the wall, hanging.' [44] }\end{array}$

'Deverbal adverbs' like tamenje 'coiled', tomoihtëe 'hung', tëkïise 'glued/ pasted' can also be used as main predicates. Structurally, such sentences still look copular (the third-person copula nai can still sometimes occur), but are best analyzed as a new kind of transitive construction (Meira 2007). Examples (20) and (21) show two such adverbial predicates, with tïpuukae 'pierced' (from puuka 'pierce [tr.]') and tonje 'surrounded' (from oomi 'surround [tr.]'). Note that Example (20) is an ergative, with a transitive subject marked by the $j a$ agent clitic.

(20) eperu (nai,) tïpuukae pïrëu ja

fruit 3.COP pierced arrow AGT

'The fruit is pierced by the arrow.'

'The arrow pierced the fruit.' [30]

(21) apuru-toh ke tonje pakoro

close-NLZR INSTR surrounded house

'The house is surrounded with a fence.'

(= someone surrounded ...) [15]

Other kinds of constructions also found in answers to where-questions are illustrated below. Example (22) has a copular, but nonlocative, sentence with a derived adverb tëpuke 'provided with a stick'; (23) and (24) have normal verbal (noncopular) sentences.

t-ëpu-ke nai, inasu
ADVLZR-stick-HAVING 3.COP toy
'The toy (= balloon) is stick-provided.' [20]
enï-pisi $\quad$ t-ee-mo-e sa
container-DIM PST-DETR-break-PST a.little
'The cup is a little broken.' [26] (lit. broke itself a little)
tuna n-ejika-n kutei pë
water 3-trickle-PRES glass on
'Water is trickling down the glass.'

Table 1 maps the deviations from basic copular locative (CL) sentences with respect to the various semantic groups in Wilkin's implicational 
Table 1. Mapping of Tiriyó copula locatives onto the Wilkins' implicational hierarchy

\begin{tabular}{lll}
\hline VI. 'Normal locative' & CL (+adverbs only for further detail) \\
V. 'Clothing/jewelry' & CL (+adverbs only for further detail); a few 'S wears O' \\
IV. 'Handles (part/whole)' & CL (+adverbs only for further detail) \\
III. 'Negative space' & $\begin{array}{l}\text { verbal sentences ('broken'); CL usually refused } \\
\text { II. 'Stuck/tied/encircled' }\end{array}$ & $\begin{array}{l}\text { 'stuck/tied' CL (+adverbs), sometimes verbal sentences; } \\
\text { 'encircled' CL + tonje 'surrounded', often verbal }\end{array}$ \\
sentences (there is no 'around' postposition)
\end{tabular}

hierarchy (Ameka and Levinson this issue). Note that, unexpectedly, CLs are "worse" in group III "Negative space" than in group I "piercing/ trickling', and that 'surrounding' scenes are also usually non-CL (due to the absence of an 'around' postposition.)

\section{Chukchi}

The BLC in Chukchi is formed with a copula clause which includes a subject (expressing Figure), a locational adjunct (expressing Ground), and the locational/existential copula verb $w a-/-t w a-$ (word initial/word internal allomorphs).

\begin{tabular}{|c|c|c|c|}
\hline FIGURE & GROUND & & \\
\hline Porawetl?a-n & jara-cəko & nə-twa-qe & \\
\hline person-3ABS & house-INESS & HAB-be-3 & \\
\hline 'The person $\mathrm{i}$ & inside the ho & use.' & \\
\hline GROUND & & Figure & \\
\hline wak?o-cq-әjo & $\gamma$-əjękə & qepəl & nə-twa-qen \\
\hline sit-surface-co & tain-SUBLAT & ball.ABS & НАB-be-3 \\
\hline
\end{tabular}

The same constructions are used with an animate Figure (25) as with an inanimate one (26). The order of Figure and Ground can vary. The copula is frequently omitted, usually in a question with the locative interrogative such as (27).

(27) minkə nelwəli-ət (nə-twa-qena-t)?

where herd-PL hab-be-3-pl

'Where are the herds?'

It is possible that this is Russian influence (Russian has a zero copula in the present tense), but note that other Chukchi copulas are not usually omitted. For example, the equational/identity copula it-, which occurs with a complement in a special "equative" case, is rarely if ever omitted in questions or statements (28). 
(28)

$\begin{array}{llll}\text { onqen } \quad \text { jokwajo ipe } & \text { iir-u } & \text { n-it-qin } \\ \text { that.3sG.ABS duck.3sG.ABS } & \text { actually } & \text { wolf-EQU } & \text { HAB-be-3sG } \\ \text { 'That duck is actually a wolf!' } & & \end{array}$

The unmarked word order for a locative copula clause is SUBJECT (Figure) + COMPLEMENT (GROUND) + COPULA, and deviations from this word order often indicate different information structure. Thus, Example (29) was made as an assertion about the sometime presence of a Japanese cannery in a Chukchi village (e.g., 'There was once a cannery here'), rather than the basic locative function of telling where the Japanese were (e.g., 'Where was the cannery?' - 'The cannery was here'):

(29) yutku ya-twa-lena-t w?ej-plek-əl?-ət

here PERF-be-3-PL grass-shoe-NMZR-ABS.PL

'There were Japanese here.'

The locational adjuncts in the BLC may be case-marked nominals (as in examples [25], [26], locational adverbs [29], [30] or postpositional phrases [31]).

(30) mran-qac ləyen nə-twa-qen $=? \mathrm{~m} /$ umk-etə $\mathrm{n}$-ine-yite-qin right-SIDE foc HAB-be-3=EMPH tree-ALL HAB-TR-look-3

'He's on the RIGHT, looking at the bush.'

(31) tətl-ək qaca nə-twa-qen

door-LOC beside.PP HAB-be-3

'It is beside the door.'

The Chukchi BLC is regularly used in the "core basic locative construction scenes" (Cluster VI in the Wilkins' implicational hierarchy), indicating easily moved inanimate Figure located in nonattached fashion with respect to Ground (note this typology does not consider animate Figures). Scenes of cluster IV "Part/whole" (32) and cluster V "Clothing" (33a) also tend to occur with BLC, although full verbal clauses with a resultative are also common, e.g., (33b).

(32) yutke-yjit linlin wa-rkən

here-ORIENT heart.ABS be-PROG

'My heart is through here'
a. rəlyəkw-ən rəly-ək
ring-ABS finger-LOC
'The ring is on the finger.'
b. relyəkw-əlyən nə-jp-ətwa-qen rəly-ək ring-sing.abs hab-don-result-3sg finger-loc 'The ring is donned on the finger.'


The other types of scenes (I, II and III) dealt with in the Wilkins' hierarchy are typically described using a full verbal clause, e.g., "Negative space" (34), 'Stuck/tied/encircled' (35), (36), and 'Piercing' (37):

(34) koji-ən ya-cyat-len

cup-ABS PERF-crack-3sG

'The cup is cracked.'

utt-əqej-ək ye-nt-əlin car
stick-DIM-LOC PERF-put-3sG balloon
'The balloon is put on the stick.'

(36) jara-nə ya-koral-len

house-ABS PERF-corral-3SG

'The house is corralled (i.e. the house is within the fence/corral).'

(37) tetenpatjoly-ək yəryoca ye-ntənpet-lin titi-nə pincushion-LOC above PERF-pierce-3sG needle-ABS

'The needle is stuck in the top of the pincushion.'

Most Chukchi posture verbs in their bare form have the dynamic meaning of 'getting into a posture'. Derivations with the resultative suffix -twa are used to indicate static posture. Note that the resultative suffix -twa- is identical to the noninitial form of the copula. Many instances of the resultative are reminiscent of compound verbs (in which a verb encoding manner is compounded with a verb indicating motion); this suggests a transparent path of grammaticalization, BE-verb to resultative. These resultative forms may be used for objects in a noncanonical or otherwise salient posture, as shown in Examples (38)-(41).

təttatjoly-ən renm-ək nə-twetca-twa-qen

ladder-ABS wall-LOC HAB-stand-result-3

'The ladder is standing at the wall.'
kelike
nə-twetca-twa-qen ctol-ətkən-ək
mac-aankə

book.ABS HAB-stand-RESULT-3 table-SUPERESS-LOC approx-open

'The book stands on the table a little bit open.'

(40) kenunen nə-ran?aw-ətwa-qen umk-ək

staff.ABS HAB-be.alongside-RESULT-3 tree-LOC

'The staff is up alongside of the tree.'
jily-ək
nə-jme-twa-qena-t
ewir?-ət
string-LOC
HAB-hang-RESULT-3-PL clothing-ABS.PL
'The clothing is hanging on the string'

It should be noted that the verbs wakPo-twa 'be sitting' and apaqala-twa 'be lying' usually occur with animate Figures only. For inanimate Figures forms indicating external agency (i.e., verbs of manipulation) are preferred, e.g., (42). 
ctol-ətkən-ək butilka-t nə-np-ətwa-qaat

table-SUPERESS-LOC bottle-ABS.PL HAB-knock.down-RESULT-3PL

'The bottles are knocked down (or: They've knocked down

bottles) on the table.'

Etymologically, the forms 'sit' and 'lie' strongly assume an animate subject, since the nonresultative forms include a semantic component of volitionality or control by the subject; it is likewise possible that the examples of inanimate Figures with 'stand' (38) and (39) are the results of interference from Russian (there are no unelicited examples of 'stand' with an inanimate subject in my corpus). Resultatives formed from verbs of manipulation as in (42), or from specialized verbs of inanimate position as in (40) and (41) do not assume any animacy on the part of the subject of the clause, and are the usual way to indicate positional information in Chukchi.

\section{Lavukaleve}

In the construction which fulfils the basic locative function in Lavukaleve all positional and configurational information comes from locational adjuncts. There is a single existential verb in the BLC, but it does not express positional or configurational information. The Lavukaleve BLC only expresses the position of the Figure with respect to the Ground, and contains no information on configuration of the Figure. However such information can be expressed in an extension of the BLC, which does involve verbs expressing positional information. The positional verbs come in under one of two conditions: when the Figure is human; or when the Figure is in an informationally salient noncanonical relationship with respect to its Ground. The expression of the basic locative function in Lavukaleve can be schematized FIgURE + Ground PHRASE + (FOCUS.MARKER) + EXIST.

For example, the extended BLC sentence in (44) can be given in answer to the "where" question in (43).

$\begin{array}{lll}\text { Kuisa } & \text { la } & \text { vasi-a? } \\ \text { bottle(F) } & \text { SG.F.ART } & \text { be.where-SG.F }\end{array}$

'Where is the bottle?'

Figure

Ground

(44)

\begin{tabular}{|c|c|c|c|}
\hline $\begin{array}{l}{[\text { Kuisa }} \\
\text { bottle(F) }\end{array}$ & $\begin{array}{l}\text { la] } \\
\text { SG.F.ART }\end{array}$ & $\begin{array}{l}\text { [beko } \\
\text { stone(F) }\end{array}$ & $\begin{array}{l}\text { o-tat] } \\
\text { 3sG.F.O-on.top }\end{array}$ \\
\hline
\end{tabular}

3sG.S-exist

'The bottle is on top of the stone.' [10] 
The expression of the Ground phrase is conditioned by the class of noun referring to the Ground object. There are three classes of noun, 'common', 'locational' and 'place' nouns. Common nouns enter into a postpositional phrase, as in (44). There are about a dozen postpositions in Lavukaleve, including na 'in, on, etc'; nam 'to'; namula 'from'; hal 'above'; tat 'on top of'; hamail 'facing'; fataran 'opposite' and kelei 'near'. There are also complex postpositional phrases, containing stacked adjuncts, as in (45). A restricted subclass of nouns, 'locational nouns', use a locative suffix in ground phrases referring to general static location (46). Locative marked adjuncts do not form full noun phrases, and do not take articles or modifiers (Terrill, 2003: 161). The locational noun class includes words for time, places, body parts, positions, but membership of the class is not predictable from semantics. Proper names referring to places can be common nouns (taking a postpositional phrase), locational nouns (taking the locative suffix), or may belong to the restricted class of 'place nouns', which function as adjuncts without any overt marking (47).

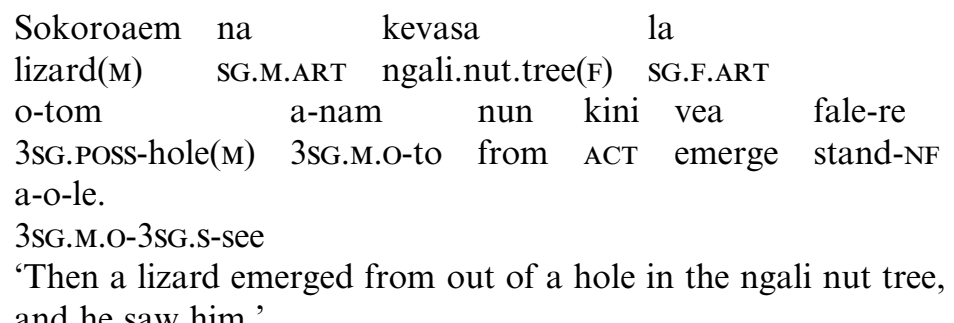

Olang ali o'ase-n ngoa me-m.
because man(M) bush-LOC stay HAB-sgm
'Because he had been staying in the bush.'

$\begin{array}{llll}\text { Aka gali } & \text { ga } & \text { ali } & \text { e-le } \\ \text { then stone.canoe(N) } & \text { SG.N.ART } & \operatorname{man}(\mathrm{M}) & \text { 3sG.N.ART-see } \\ \text { e-liki-vele } & \text { Adina } & \text { fi } & \text { o-ae-re. } \\ \text { 3sG.N.O-want-SuCC } & \text { Yandina } & \text { 3sG.N.FOC } & \text { 3sG.S-go.up-FUT } \\ \text { 'And if anyone wants to see the stone canoe he must go up to } & \\ \text { Yandina.' }\end{array}$

The focus marker in the Lavukaleve BLC is not completely obligatory, but speakers prefer to make overt the information structure by marking focus. The most typical focus construction in the BLC is the sentenceinternal focus construction marking the Ground phrase constituent (Terrill 2003: 292-293).

A further elaboration of the BLC involves a verb specifying the position of the Figure. Any semantically suitable verb, or a derived adverbial (e.g., komori-l ('turn something upside down'-Locativizer) 'in a turned-upside- 
down position') can appear in this position, as in (48) using the adverbial fufu-re.

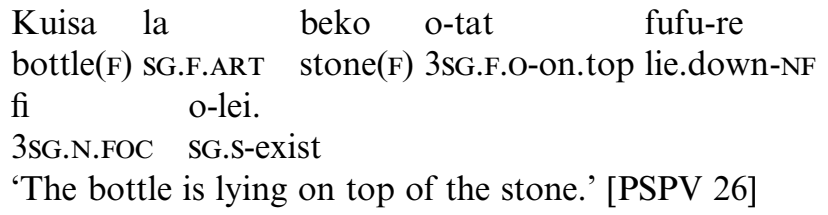

The positional verb/derived adverbial is optional in standard expressions of Figure/Ground locative relations, but is generally not used. It is more likely to occur describing two types of situations: those with noncanonical configurations, and those with animate Figures.

If a Figure is in a noncanonical relationship with respect to its Ground, the positional verbs are more likely to be used. If a bottle is upright speakers are more likely to just say 'the bottle is on the table', but if it is lying down speakers are more likely to be specific about its position: 'the bottle is lying on the ground'. In canonical situations speakers very rarely volunteer positional verbs, as shown by the fact that for all of the situations in the PSPV a positional verb could be used, whereas for most of the TRPS scenes positional verbs were not used. In Example (49), a canonical configuration involving a bottle standing upright on a table, Lavukaleve speakers did spontaneously volunteer a positional verb, and the verb ligu 'hang' was always used with hanging scenes as in (50):

$\begin{array}{lllll}\text { Kuisa } & \text { la } & \text { foia } & \text { tevo } & \text { la } \\ \text { bottle(F) } & \text { SG.F.ART } & \text { PN.MED.SG.F } & \text { table(F) } & \text { SG.F.ART } \\ \text { O-tat } & \text { fifi-re } & \text { o-lei. } & & \\ \text { 3sG.F.O-on.top sit-NF } & \text { 3sG.S-exist } \\ \text { 'The bottle is sitting on top of the table.' [PSPV 37] }\end{array}$

\begin{tabular}{|c|c|c|c|c|}
\hline Kemus & ga & houla & o-toeal & va \\
\hline $\operatorname{rope}(\mathrm{N})$ & SG.N.ART & $\operatorname{tree}(\mathrm{F})$ & 3sG.POSs-branches(PL) & PL.ART \\
\hline vo-na & ligu-re & fi & o-lei. & \\
\hline 3PL.o-in & hang-NF & 3SG.N & 3sG.S-exist & \\
\hline
\end{tabular}

'The rope is hanging on the branches of the tree.' [PSPV 57]

Furthermore, positional verbs are far more likely to be used than not when the Figure is animate. They can always be used with inanimate Figures, but are only rarely used with inanimate Figures in natural contexts; there were only a handful of examples of positional verbs with inanimate Figures used in spontaneous speech.

Other kinds of answers to "where" questions occur. The BLC was used for all the semantic types elicited by the TRPS book except for "Negative space" and "piercing'/"rain on window'. For "negative space" scenes, 
resultative constructions are used (similar to 'the cup is broken', 'the clothing is torn') although a BLC alternative to the latter was also possible ('there is a hole in the clothing'). For piercing, a resultative construction and a chaining construction were used ('the papers are pierced on the needle'; 'the needle goes through apple and out the other side'); and for 'rain-on-window', a simple verbal clause was used ('rain wets the door'). An example of a resultative construction is given in (51).

(51) Paniken ga ta-taua.

$\operatorname{cup}(\mathrm{N}) \quad$ SG.N.ART REDUP-break

'The cup is broken.' [26]

To summarize, postural predicates in Lavukaleve do not have existential power; their absence, though, does have implicatures. If a positional verb is used, it implies that the Figure is not in its normal positional with respect to the Ground. Thus if a positional verb is not used, it implies that the Figure is in its normal position with respect to the Ground.

\section{Discussion and conclusions}

These case studies described in this article have allowed the testing of a number of predictions about positional verb systems relating to the typology of locative predication, described in Section 1 (see also Ameka and Levinson this issue).

During the design of the experimental investigation of Positional verb typology described in Ameka and Levinson (this issue), the following conjecture was proposed:

- AMEKA's CONJECTURE:

The higher a language is in the hierarchy $0-\mathrm{I}-\mathrm{II}-\mathrm{III}$, the greater probability of using human posture verbs with inanimate Figures.

The evidence presented in this chapter does not seem to offer clear support to this prediction. Tiriyó, which was analyzed as "Type I", does indeed not use human posture verbs, but allows adverbial modifiers derived from posture verbs.

With rare exceptions, Chukchi (Type I) does not use human posture verbs with inanimate Figures; in the corpus, the exceptions come from elicited rather than spontaneous texts, and may be due to Russian influence. Chukchi has a rich set of verbs indicating physical configuration which are not based on human posture.

Lavukaleve (Type I) allows human posture verbs with inanimates, but they are rare in spontaneous texts. On the other hand, Saliba, analyzed as 
"Type 0", can use human posture verbs with a semantically constrained set of inanimate Figures (rigid objects with bases or a long axis); they 'sit' on a base, 'stand' with a vertical long axis, and 'lie' if turned on the side from the base, or if they have a horizontal long axis. ${ }^{3}$

In sum, there seems to be no structural disincentive for Tiriyó to use postural verbs in (nonbasic) locative clauses; despite this Tiriyó doesn't allow postural verbs at all in locative clauses, selecting instead adverbials derived from posture verb stems. Chukchi, Saliba and Lavukaleve do allow some human postural verbs with inanimate Figures. In Saliba and Lavukaleve inanimate subject clauses with human postural verbs are apparently the normal way of expressing dispositional information; however, in Chukchi there are other dispositional verbs available which do not make reference to human posture, and there is evidence that the use of human posture verbs with inanimate Figures is the result of interference. Therefore it can be concluded that languages on the lower end of the typology of locative predication, such as those investigated in this article, do allow human posture verbs in some contexts, with Saliba (Type 0) doing so more readily than Tiriyó (Type I). "Ameka's conjecture", at least in its unmodified form, is not supported by this data.

On the basis of a large sample (410 languages, including Chukchi), Stassen identifies one of the basic features of the prototypical location expression to involve "the presence of a supportive lexical item which has the morphosyntactic features of a verb" (Stassen 1997: 55); a large majority of the languages in his sample have a locative verb. Saliba is the only language in our sample with a verbless construction as the sole construction used in the basic locative function, and even for Saliba verbal locative clauses do exist in nonbasic functions. Stassen suggests two "CrossLinguistic Tendencies in Locational Encoding” (1997: 56).

- Stassen's CRoss-Lingusitic TENDENCIES:

(a) If a language has a unique encoding of locational predicates, that encoding will involve the use of a locative verb.

(b) If a language allows predicate encoding by way of a support verb, locational predicates will be among the predicate categories which employ this encoding.

With respect to tendency (a), Tiriyó has verbal and nonverbal encoding, so the prediction does not apply to it. Chukchi and Lavukaleve both allow only verbal encoding of the locational predicate, which is in accord with (a). Saliba, however, has a single locational strategy involving a nonverbal particle, which goes against the proposed universal tendency. 
All the four languages accord with tendency (b): Tiriyó, Chukchi and Lavukaleve have verbs in a number of copula functions, and in all cases this includes the locative.

Ameka and Levinson (this issue) have also made the following prediction:

- LEVINSON'S PRAGMATIC PREDICTIONS:

(a) In languages where a verbless locative structure competes with a verby one, the verbless structure will be favored in descriptions of stereotypical situations.

(b) Languages which favor unmarked Ground nominals (no case or adposition) will not permit verb deletion.

(c) Languages which do not allow locative verb deletion will in certain stereotypical circumstances allow contraction of the Ground clause, e.g., adposition/locative case deletion, article deletion, etc.

In the sample reported in this article, the prediction (a) applies only to Tiriyó and Chukchi (Saliba has no verbal locative, and Lavukaleve has no verbless locative). However, neither in Tiriyó nor in Chukchi is it clear what semantic or pragmatic difference is indicated by selection of a verbal or verbless construction. The Tiriyó copula nai is optional in all types of copula clause, and doesn't seem to have anything to do with stereotypicality. In Chukchi the locative/existential copula is optional in clauses with unmarked (stative) temporal reference, but absence of this copula correlates more closely with "elicitation register" (i.e., in contrast to natural descriptions) than any internal semantics of the clause.

None of the languages investigated in this article favor unmarked Ground nominals, so prediction (b), about the inadmissibility of verb deletion for such languages, cannot be tested.

Lavukaleve is the only language in the study which does not allow locative verb deletion; Levinson's pragmatic prediction (c), concerning contraction of locative phrases in certain stereotypical contexts in such languages, finds partial confirmation. Lavukaleve has three noun subclasses defined by the special, contracted forms in locative functions. There is a locative suffix $-n$ which is only used with a lexically determined subset of nouns, including some (but not all) terms from semantic fields of time (e.g., lara-n 'in the day'), place names (Lavukale-n 'in the Russell Islands'), place nouns (furinge-n 'on the weathercoast'), positional nouns (erea- $n$ 'in front'), body parts (gata- $n$ 'on the top of the head'), and a few others (aro-n 'in a language'). Another subset of nouns can be used in the bare form in locative function (others use the $-n$ suffix discussed above, or only appear in postpositional phrases). Tiriyó, Chukchi and 
Table 2. Preferred use of the basic locative construction (BLC) in the four languages for the six types of Figure/Ground relationships in Wilkins' implicational hierarchy

\begin{tabular}{lllll}
\hline Type of Figure/Ground relationship & Chukchi & Tiriyó & Saliba & Lavuk. \\
\hline I. Piercing (22, 70, 30); trickling (48) & - & - & - & - \\
II. Stuck $(3,35)$; tied $(55,4)$ & - & Tied: - & - & - \\
& & Stuck: + & & \\
III. Negative space $(26,18)$ & - & - & - & - \\
IV. Part/whole $(61,66)$ & + & + & - & + \\
V. Clothing/jewelry $(5,21,10)$ & + & + & + & + \\
VI. Normal locative $(59,1,2,19,16)$ & + & + & + & + \\
\hline
\end{tabular}

Saliba don't have nominal subclasses characterized by contracted locative expressions.

Finally, Table 2 shows in summary form at what point in Wilkins' implicational hierarchy each of the languages studied departs from the BLC. Only preferred usages are shown, rather than possible uses (in which case the BLC would cover slightly more ground). A positive answer for preferred use of the BLC means that the BLC was preferred as the description of the concepts shown in scenes in the TRPS, but does not mean that it was the preferred description of actual TRPS pictures. This is an important qualification for some scenes. For example in Lavukaleve, the BLC was used for scenes 3 and 35 (the "stuck" scenes), but it did not express the concept of STICKING. To express this concept a sentence with a positional verb must be used in Lavukaleve, rather than the BLC. Thus Lavukaleve scores a response of "no" for STICKING, even though scenes 3 and 35 were actually both expressed with the BLC.

Tiriyó is notable in that it allows the BLC for "stuck", but not for "negative space", thus contradicting the predictions of the Wilkins' implicational hierarchy.

As shown, the four languages described in this article are in partial agreement with the typology proposed by Ameka and Levinson (this issue), with respect to the hypotheses concerning zero-/one-verb languages and to their pattern of deviation from the Wilkins hierarchy. A few characteristics deserve further mention.

Two of the four languages - Saliba and Lavukaleve - have real static posture verbs, like English sit, stand, lie, hang, while the other two Tiriyó and Chukchi - have change-of-state verbs for assuming a given posture or placing something in a given posture from which posturedescribing adverbials can be derived, a situation reminiscent of Spanish, with (mostly) deverbal adjectives like sentado 'sitting', acostado 'lying down', parado or de pie 'standing', colgado 'hanging'. 
Interestingly, the static posture verb languages Saliba, Lavukaleve and English appear to be, from the formal point of view, closer to being true small-set positional (Type III) languages than Tiriyó, Chukchi or Spanish, with change-of-state verbs. "static-verb" languages already have good stative intransitive verbs to describe posture. In fact, if one compares English sit, stand, lie, and hang to the Type III language Dutch zitten, staan, liggen, and hangen, one is struck by the fact that the two sets of verbs are cognate and very close in meaning, yet the Dutch set forms a real positional verb system, while the English set does not. It may be that languages like English, Saliba and Lavukaleve have a potential positional verb system, while Dutch and other Type III languages have an actual positional verb system.

Received 8 June 2005

Revised version received

5 March 2007
Max Planck Institute for Psycholinguistics

Monash University

University of Leiden

Radboud University Nijmegen

\section{Appendix A. Abbreviations}

$\begin{array}{ll}\text { ABS } & \text { absolutive } \\ \text { ADVLZR } & \text { adverbializer } \\ \text { APP } & \text { applicative } \\ \text { ART } & \text { article } \\ \text { BLC } & \text { Basic Locative Construction } \\ \text { BLF } & \text { Basic Locative Function } \\ \text { CONJ } & \text { conjunction } \\ \text { COP } & \text { copula } \\ \text { DET } & \text { determiner } \\ \text { DETR } & \text { detransitive } \\ \text { DIM } & \text { diminutive } \\ \text { EMPH } & \text { emphatic } \\ \text { EQU } & \text { equative } \\ \text { F } & \text { feminine } \\ \text { FOC } & \text { focus } \\ \text { HAB } & \text { habitual } \\ \text { INESS } & \text { inessive } \\ \text { LOC } & \text { locative } \\ \text { MED } & \text { medial } \\ \text { N } & \text { neuter } \\ \text { NEG } & \text { negative } \\ \text { NF } & \text { nonfuture } \\ \text { NMZR } & \text { nominalizer } \\ \text { ORIENT } & \text { orientative }\end{array}$




$\begin{array}{ll}\text { PERF } & \text { perfect } \\ \text { PL } & \text { plural } \\ \text { PN } & \text { pronoun } \\ \text { PP } & \text { postposition } \\ \text { PRES } & \text { present } \\ \text { PROG } & \text { progressive } \\ \text { PRSUP } & \text { presuppositional marker } \\ \text { PSPV } & \text { Picture Series for Positional Verbs (Ameka et al. 1999) } \\ \text { PST } & \text { past } \\ \text { RED } & \text { reduplicated } \\ \text { RESULT } & \text { resultative } \\ \text { SG } & \text { singular } \\ \text { SUBLAT } & \text { sublative } \\ \text { SUPERESS } & \text { superessive } \\ \text { TAM } & \text { tense-aspect-mood } \\ \text { TRPS } & \text { Topological Relations Picture Series (Bowerman and Pederson 1993) }\end{array}$

\section{Notes}

* Correspondence address: Michael Dunn, Max Planck Institute for Psycholinguistics, P.O. Box 310, 6500 AH Nijmegen, The Netherlands. E-mail: michael.dunn@mpi.nl.

1. Note that kabasi 'hang' does not normally occur as an unreduplicated stem (except if causativized).

2. The difference in meaning caused by the presence or absence of an explicit copula (like e.g., the third-person form nai) is not clear. Sentences without copulas are more frequently used for identifying entities (e.g., 'John is that one', with a pointing gesture). However, the same sentences with copulas are accepted for the same contexts and even also sometimes spontaneously produced.

3. Note that bottles are both elongated and have bases, meaning they can occur with either 'sit' or 'stand'; a rounded pot can only 'sit', sticks can only 'stand'.

\section{References}

Ameka, Felix; De Witte, Carlien; and Wilkins, David (1999). Picture series for positional verbs: eliciting the verbal component in locative descriptions. In Field Manual 1999, David Wilkins (ed.), 48-56. Nijmegen: Max Planck Institute for Psycholinguistics.

Bowerman, Melissa and Pederson, Eric (1993). Topological relations picture series. In Manual for the Space Stimuli Kit 1.2, Eve Danziger and Deborah Hill (eds.), 40-50. Nijmegen: Max Planck Institute for Psycholinguistics.

Dunn, Michael (1999). A grammar of Chukchi. Unpublished doctoral dissertation, Australian National University.

Durst-Anderson, Per (2006). Location in Danish as opposed to English and Russian. In Grammatica: Festschrift in Honour of Michael Herslund, Henning Nølke, Irène Baron, Hanne Korzen, Iørn Korzen, and Henrik H. Müller (eds.), 69-84. Bern: Peter Lang.

Kita, Sotaro and Walsh Dickey, Laura (eds.) (1998). Annual report 1998. Max Planck Institute for Psycholinguistics. 
Margetts, Anna (1999). Valence and Transitivity in Saliba, an Oceanic Language of Papua New Guinea. MPI Series in Psycholinguistics. Nijmegen: Max Planck Institute for Psycholinguistics.

Meira, Sérgio (2007). A Grammar of Tiriyó. Berlin and New York: Mouton de Gruyter.

Sinha, Chris (1998). Language and Representation: A Socio-Naturalistic Approach to Human Development. New York: New York University Press.

— and Tanya Kuteva (1995). Distributed spatial semantics. Nordic Journal of Linguistics 18(2), 167-199.

Stassen, Leon (1997). Intransitive Predication. Oxford: Clarendon Press.

Talmy, Leonard (1975). Semantics and syntax of motion. In Syntax and Semantics, Volume 4, John Kimball (ed.), 181-238. New York: Academic Press.

-(1985). Lexicalization patterns: semantic structure in lexical forms. In Language Typology and Syntactic Description, Volume 3: Grammatical Categories and the Lexicon, Timothy Shopen (ed.), 36-149. Cambridge: Cambridge University Press.

- (2000). Towards a Cognitive Semantics, Volume 2: Typology and Process in Concept Structuring. Cambridge, MA: MIT Press.

Terrill, Angela (2003). A Grammar of Lavukaleve. Berlin and New York: Mouton de Gruyter.

Zlatev, Jordan (1997). Situated Embodiment: Studies in the Emergence of Spatial Meaning. Stockholm: Gotab.

- (2006). Semantics of spatial expressions. In Encyclopedia of Language and Linguistics, 2nd ed., Vol. 11, Keith Brown (ed.), 173-180. Oxford: Elsevier. 